\title{
Thyroid Disease Is Associated with Higher Age- Related Macular Degeneration Risk: Results from a Meta-Analysis of Epidemiologic Studies
}

\author{
Ziming $\mathrm{Xu}^{\mathrm{a}}$ Mei Zhang ${ }^{\mathrm{b}}$ Qing Zhang ${ }^{\mathrm{a}}$ Tingjuan $\mathrm{Xu}^{\mathrm{c}}{ }^{\mathrm{d}}$ Liming Tao ${ }^{\mathrm{a}}$

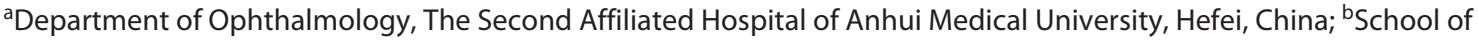

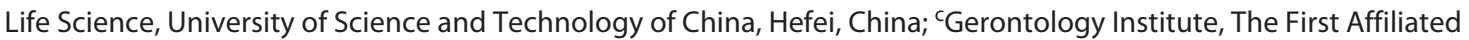 \\ Hospital of USTC, Division of Life Sciences and Medicine, University of Science and Technology of China, Hefei, \\ China; ${ }^{d}$ Anhui Provincial Key Laboratory of Tumor Immunotherapy and Nutrition Therapy, Hefei, China
}

\section{Keywords}

Thyroid hormone $\cdot$ Thyrotropin · Thyroid medication · Agerelated macular degeneration $\cdot$ Meta-analysis

\begin{abstract}
Background: Although epidemiologic studies have suggested that thyroid disease may be a risk factor for age-related macular degeneration (AMD), this finding is still controversial. Objectives: The aim of this meta-analysis was to investigate whether an association exists between thyroid disease and medication and AMD in epidemiologic studies. Methods: We searched PubMed, EMBASE, and Google Scholar from their inception to March 2020 for cross-sectional, case-control, and cohort studies that assessed thyroid function and AMD risk. Data from selected studies were extracted, and a meta-analysis was performed using fixed-effects or random-effects models. The statistical heterogeneity $\left(I^{2}\right)$ among studies and the possibility of publication bias were evaluated. If $R^{2}>50 \%$, a significant heterogeneity existed among studies, and a random-effects model was used to calculate the pooled RR. Otherwise, a fixed-effects model was performed. Results: A total of 13 epidemiologic studies that consisted of 7 thyroid disease and 7 thyroid medication studies were included. Statistically significant heterogeneity
\end{abstract}

was observed in the study results $\left(I_{\text {thyroid disease }}^{2}=80.1 \%\right.$; $\left.R_{\text {thyroid medication }}=69.0 \%\right)$. A significant positive association was found between thyroid disease and AMD, with an overall relative risk (RR) of 1.25 (95\% Cl: 1.02, 1.54). However, there was no statistical association between thyroid medication and AMD risk (pooled RR 1.26 [95\% Cl: 0.92-1.72]). Egger's test indicated that there was no significant publication bias for thyroid disease ( $p=0.889$ ) or thyroid medication ( $p$ $=0.226$ ). Conclusions: Our findings indicate that thyroid disease is associated with higher AMD risk. Thyroid disease prevention strategies may have a significant effect on the prevention of AMD and warrant further evaluation.

(c) 2021 S. Karger AG, Basel

\section{Introduction}

Age-related macular degeneration (AMD) is a prevalent disease leading to blindness and involves the loss of a person's central field of vision. Globally, the prevalence of AMD, which is the leading cause of irreversible loss of vision among elderly individuals, is expected to increase with population aging, ranking third as a cause of blindness after cataract and glaucoma [1]. AMD is a complex multifactorial disease accounting for $8.7 \%$ of cases of karger@karger.com

www.karger.com/ore

() 2021 S. Karger AG, Base

Karger!
Correspondence to:

Tingjuan Xu, xutingjuan@163.com

Liming Tao,lmtao9@163.com 
blindness worldwide, and its prevalence is increasing and spreading [2]. The global population is expected to grow to approximately 9.5 billion by 2050 , and it was estimated that there were nearly 2.4 billion people $\geq 60$ years in 2050 [3]. The prevalence of AMD was $2.4 \%$ in African Americans, $4.2 \%$ in Hispanics, $5.4 \%$ in Whites, and $4.6 \%$ in Chinese individuals aged $45-85$ years, and the estimated total prevalence of any AMD was 4.2\% [4]. The pathophysiological mechanisms leading to AMD are not fully understood, but genetic tendencies and environmental factors, including the use of tobacco and nutritional factors, are believed to play an important role [5]. Recently, thyroid hormone (TH) signaling has been implicated in the pathogenesis of AMD [6].

Human retinal pigment epithelial cells express TH receptors and seem to be a direct target for TH [7]. Population studies have revealed that high serum thyrotropin levels are associated with retinal arteriolar narrowing [8]. Animal studies have demonstrated that moderate levels of pre- and postnatal TH insufficiency lead to alterations in visual function in adult rats [9]. These findings highlight the important role of $\mathrm{TH}$ in regulating various visual functions.

Ma et al. [10] reported that suppressing TH preserves cone photoreceptors in mice with retinal degeneration, while administrating active $\mathrm{TH}$ deteriorates cones, which are known to be important factors for the development and progression of AMD. A Rotterdam study found that higher serum-free thyroxine values were associated with an increased risk of AMD [11]. Furthermore, some studies have demonstrated an association between the use of thyroid medication and the risk of AMD [12].

Previous studies have shown some evidence of a relationship between TH and AMD in the general population, although the findings have been inconsistent. In light of the above, the objective of the present meta-analysis is to evaluate the available studies related to thyroid disease and medication and AMD. Our meta-analysis analyzes relevant information published in the literature to more accurately assess the association between thyroid disease and medication and AMD.

\section{Methods}

Literature Retrieval

We performed a literature search regarding the association of thyroid disease and medication with AMD; epidemiologic studies published from inception to March 2020 were examined. An electronic search was performed using EMBASE, PubMed, and Google Scholar. The articles were searched using the following keywords

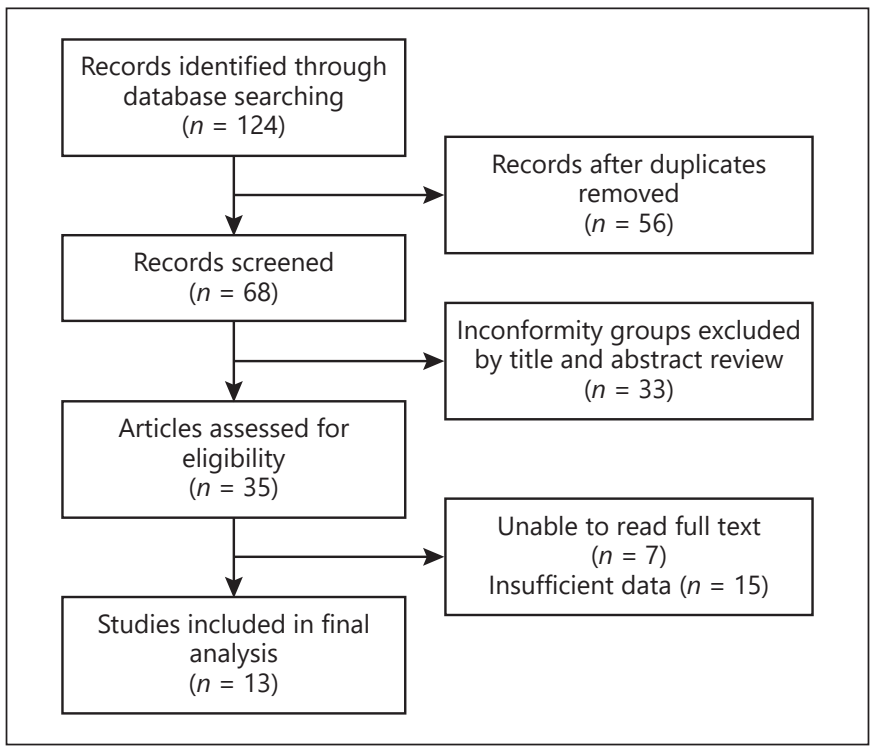

Fig. 1. References searched and selection of studies for inclusion in the meta-analysis.

in English. The following medical subject headings were used: ("thyroid function" OR "hyperthyroidism" OR "hypothyroidism" OR "thyroid disease") AND ("age-related macular degeneration" OR "AMD" OR "ARMD" OR "age-related macular disease" OR "age-related maculopathy" OR "ARM"). Searches were restricted to human studies, and all references of the selected articles were searched manually to identify relevant original studies and citations.

\section{Inclusion Criteria}

The inclusion criteria for the literature were as follows: (1) had a cross-sectional, case-control, or cohort design; (2) evaluated the association between thyroid medication or thyroid function and AMD risk; (3) performed with human subjects; and (4) had adequate data for extraction or calculation, which may be presented as the odds ratio (OR) or relative risk (RR) and 95\% confidence interval (CI). The exclusion criteria were as follows: (1) duplicate articles and (2) articles with incomplete data.

\section{Data Extraction and Quality Assessment}

The systematic review was conducted by 2 investigators who independently reviewed the titles and abstracts of all studies identified, and disagreements were resolved by consensus. We used a unified data form. The following information was recorded for each study: year, region, study design, sample size, population characteristics, main results, and matched or adjusted variables in the study design or data analysis.

\section{Statistical Methods}

The pooled RRs with corresponding 95\% CIs were considered for the effect size analysis in all analyses. When studies had multiple adjustment models, we extracted those reflecting the greatest extent of adjustment for potential confounders. Some studies separated risk estimates according to the different types of AMD (ear- 
Table 1. Characteristics of epidemiologic studies of thyroid disease and medication and AMD included in the meta-analysis

\begin{tabular}{|c|c|c|c|c|c|c|c|}
\hline Authors & Year & Region & $\begin{array}{l}\text { Study } \\
\text { design }\end{array}$ & $\begin{array}{l}\text { Sample } \\
\text { size }\end{array}$ & Population characteristics & Covariate adjustment & Main results \\
\hline $\begin{array}{l}\text { Friedman } \\
\text { et al. [14] }\end{array}$ & 1988 & USA & $\begin{array}{l}\text { Case- } \\
\text { control } \\
\text { study }\end{array}$ & 54 & $\begin{array}{l}29 \text { patients with ARMD (incident } \\
\text { thyroid disease } 20 \text { patients), } 25 \text { no } \\
\text { ARMD (incident thyroid disorder } \\
20 \text { patients) }\end{array}$ & None & $\begin{array}{l}\text { An increased scleral rigidity } \\
\text { may be a significant risk } \\
\text { factor for the development } \\
\text { of the disorder }\end{array}$ \\
\hline None [12] & 2000 & Maryland & $\begin{array}{l}\text { Case- } \\
\text { control } \\
\text { study }\end{array}$ & 118 & $\begin{array}{l}\text { Geographic atrophy (at least } 1 \text { eye } \\
\text { has definite geographic atrophy) } \\
\text { group has } 118 \text { participants, OR: } \\
1.99(1.08-3.05)\end{array}$ & None & $\begin{array}{l}\text { The increased use of } \mathrm{TH} \text { in } \\
\text { persons with geographic } \\
\text { atrophy }\end{array}$ \\
\hline Klein [20] & 2001 & USA & $\begin{array}{l}\text { Cohort } \\
\text { study }\end{array}$ & 2,819 & $\begin{array}{l}\text { In } 28 \text { subjects exposed to thyroid } \\
\text { hormones desiccated }(n=2819) \text {, } \\
6 \text { developed ARM, the OR and } \\
95 \% \text { CI are } 2.32(0.89-6.07)\end{array}$ & Adjusted for age and sex & $\begin{array}{l}\text { Many different medication } \\
\text { use had no striking } \\
\text { associations with the } 5 \text {-year } \\
\text { incidence of early ARM }\end{array}$ \\
\hline $\begin{array}{l}\text { Seddon et } \\
\text { al. [22] }\end{array}$ & 2004 & USA & $\begin{array}{l}\text { Case- } \\
\text { control } \\
\text { study }\end{array}$ & 930 & $\begin{array}{l}\text { Group } 1 \text { (no druse, } n=183 \text { ); } \\
\text { group } 2 \text { (intermediate drusen, } n= \\
\text { 200); group } 3 \text { (large drusen or } \\
\text { intermediate AMD, } n=325 \text { ); } \\
\text { group } 4 \text { (geographic atrophy or } \\
\text { neovascular AMD-advanced } \\
\text { AMD, } n=222 \text { ). Using thyroid } \\
\text { hormones were } 92 \text { participants } \\
\text { totally }\end{array}$ & None & $\begin{array}{l}\text { CRP level is an } \\
\text { independent risk factor for } \\
\text { AMD and may implicate } \\
\text { the role of inflammation in } \\
\text { the pathogenesis of AMD }\end{array}$ \\
\hline $\begin{array}{l}\text { Douglas et } \\
\text { al. [23] }\end{array}$ & 2007 & $\begin{array}{l}\text { United } \\
\text { Kingdom }\end{array}$ & $\begin{array}{l}\text { Case- } \\
\text { control } \\
\text { study }\end{array}$ & 104,176 & $\begin{array}{l}18,007 \text { participants with a } \\
\text { diagnosis of AMD ( } 1,077 \\
\text { participants used thyroid } \\
\text { hormones in the past) and } 86,169 \\
\text { controls ( } 4,487 \text { participants used } \\
\text { thyroid hormones in the past); } \\
\text { mean age: } 77.4 \mathrm{yr}\end{array}$ & $\begin{array}{l}\text { Adjusted for consultation } \\
\text { rate, observation time, } \\
\text { diabetes, heart failure, } \\
\text { hyperlipidemia, } \\
\text { cardiovascular drugs, } \\
\text { atherosclerosis, } \\
\text { hypertension, body mass } \\
\text { index, aspirin, hormone } \\
\text { replacement therapy, alcohol } \\
\text { consumption, and smoking }\end{array}$ & $\begin{array}{l}\text { No association was } \\
\text { detected between short- } \\
\text { and medium-term use of } \\
\text { antithyroids, TH, and } \\
\text { thiazide diuretics and the } \\
\text { risk of AMD }\end{array}$ \\
\hline $\begin{array}{l}\text { Bromfield } \\
\text { et al. [15] }\end{array}$ & 2011 & USA & $\begin{array}{l}\text { Cross- } \\
\text { sectional }\end{array}$ & 9,677 & $\begin{array}{l}\text { The } 2008 \text { National Health } \\
\text { Interview Survey (NHIS) served } \\
\text { as the data source for this study, } \\
\text { participants with AMD were } 356 \text {. } \\
\text { OR: } 1.59(1.10-2.30)\end{array}$ & $\begin{array}{l}\text { Adjusted for age, sex, and } \\
\text { race }\end{array}$ & $\begin{array}{l}\text { Literature indicates a } \\
\text { possible relationship } \\
\text { between AMD and } \\
\text { hypothyroidism }\end{array}$ \\
\hline $\begin{array}{l}\text { Park et al. } \\
{[16]}\end{array}$ & 2014 & Korea & $\begin{array}{l}\text { Cross- } \\
\text { sectional }\end{array}$ & 14,352 & $\begin{array}{l}14,352 \text { subjects, early ARMD } \\
\text { patients }(6.02 \%) \text { have } 50 \text { patients } \\
\text { with thyroid disease and no } \\
\text { ARMD group has } 631 \text { patients } \\
\text { with thyroid disease; late ARMD } \\
\text { patients }(0.060 \%) \text { have } 2 \text { patients } \\
\text { with thyroid disease and no } \\
\text { ARMD group has } 631 \text { patients } \\
\text { with thyroid disease }\end{array}$ & None & $\begin{array}{l}\text { Nonoverweight status and } \\
\text { higher HDL levels, } \\
\text { generally assumed as } \\
\text { positive health indicators, } \\
\text { as well as anemia and } \\
\text { hepatitis B infection had } \\
\text { harmful associations with } \\
\text { AMD in our study }\end{array}$ \\
\hline $\begin{array}{l}\text { Chaker et } \\
\text { al. [11] }\end{array}$ & 2015 & $\begin{array}{l}\text { The } \\
\text { Netherlands }\end{array}$ & $\begin{array}{l}\text { Cohort } \\
\text { study }\end{array}$ & 5,572 & $\begin{array}{l}816 \text { patients with thyroid disorder } \\
\text { (incident ARMD } 109 \text { patients), } \\
4,756 \text { euthyroid subjects (incident } \\
\text { ARMD } 696 \text { patients) }\end{array}$ & None & $\begin{array}{l}\text { It indicated an intrinsic } \\
\text { deleterious effect of TH on } \\
\text { AMD, and TH could even } \\
\text { play a role in the early stage } \\
\text { of development of AMD }\end{array}$ \\
\hline
\end{tabular}


Table 1 (continued)

\begin{tabular}{|c|c|c|c|c|c|c|c|}
\hline Authors & Year & Region & $\begin{array}{l}\text { Study } \\
\text { design }\end{array}$ & $\begin{array}{l}\text { Sample } \\
\text { size }\end{array}$ & Population characteristics & Covariate adjustment & Main results \\
\hline $\begin{array}{l}\text { Tsai et al. } \\
{[17]}\end{array}$ & 2015 & $\begin{array}{l}\text { Taiwan, } \\
\text { China }\end{array}$ & $\begin{array}{l}\text { Case- } \\
\text { control } \\
\text { study }\end{array}$ & 29,958 & $\begin{array}{l}\text { 4,993 patients with ARMD } \\
\text { (incident thyroid disorder } 177 \\
\text { patients), 24,965 no ARMD } \\
\text { (incident thyroid disorder } 673 \\
\text { patients) }\end{array}$ & None & $\begin{array}{l}\text { This study provides large- } \\
\text { scale, population-based } \\
\text { evidence that AMD, } \\
\text { especially nonexudative } \\
\text { AMD, is independently } \\
\text { associated with an } \\
\text { increased risk of } \\
\text { subsequent AD or senile } \\
\text { dementia development }\end{array}$ \\
\hline $\begin{array}{l}\text { Gopinath et } \\
\text { al. [18] }\end{array}$ & 2016 & Australia & $\begin{array}{l}\text { Cohort } \\
\text { study }\end{array}$ & 900 & $\begin{array}{l}73 \text { patients with thyroid disorder } \\
\text { (incident ARMD } 28 \text { patients), } 827 \\
\text { euthyroid subjects (incident } \\
\text { ARMD } 216 \text { patients); participants } \\
\text { who reported current use of } \\
\text { thyroxine ( } n=67 ; 7.3 \% \text { ) versus } \\
\text { those who were not current users } \\
\text { ( } n=839 \text { ) had a } 68 \% \text { increased } \\
\text { risk of incident AMD, } \\
\text { multivariable-adjusted OR } 1.68 \\
\text { (95\% CI: } 1.01-2.82 \text { ) }\end{array}$ & $\begin{array}{l}\text { None/adjusted for smoking, } \\
\text { fish consumption, and CFH } \\
\text { and ARMS2 SNPs }\end{array}$ & $\begin{array}{l}\text { Overt hyperthyroidism was } \\
\text { independently associated } \\
\text { with an increased risk of } \\
\text { incident AMD }\end{array}$ \\
\hline $\begin{array}{l}\text { Reitmeir et } \\
\text { al. [24] }\end{array}$ & 2016 & Germany & $\begin{array}{l}\text { Cross- } \\
\text { sectional }\end{array}$ & 822 & $\begin{array}{l}\text { Among all } 822 \text { participants, } 465 \\
\text { participants ( } 56.6 \%) \text { reported the } \\
\text { presence of cataracts, glaucoma, } \\
\text { corneal, or retinal disorders. } \\
\text { Associate AMD with thyroid } \\
\text { therapy. OR: } 0.35(0.14-0.87)\end{array}$ & None & $\begin{array}{l}\text { The significantly higher } \\
\text { risk for glaucoma in males } \\
\text { were treated with thyroid } \\
\text { hormones }\end{array}$ \\
\hline $\begin{array}{l}\text { Abdelkader } \\
\text { and Abass } \\
{[19]}\end{array}$ & 2019 & Egypt & $\begin{array}{l}\text { Cross- } \\
\text { sectional } \\
\text { study }\end{array}$ & 1,480 & $\begin{array}{l}950 \text { patients with thyroid disorder } \\
\text { (incident ARMD } 255 \text { patients), } \\
63.6 \pm 5.1 \text { yr; } 530 \text { euthyroid } \\
\text { subjects (incident ARMD } 80 \\
\text { patients), } 65.8 \pm 5.2 \mathrm{yr}\end{array}$ & None & $\begin{array}{l}\text { There was an increase in } \\
\text { ARMD incidence in } \\
\text { patients with abnormal T4 } \\
\text { and T3 and in patients } \\
\text { using thyroxine }\end{array}$ \\
\hline
\end{tabular}

$\mathrm{TH}$, thyroid hormone; AMD, age-related macular degeneration.

ly AMD, advanced AMD, and dry AMD), and any report of AMD effect was included. The heterogeneity test was performed by using Cochran's Q and $I^{2}$ statistics [13]. Statistical significance for heterogeneity was considered if $p$ value was $<0.05$ or $I^{2}$ was $>50 \%$, and the summary estimate on the basis of the random-effects model is presented; otherwise, a fixed-effects model was performed. Publication bias was estimated using funnel plot graphics and Begg's and Egger's tests.

\section{Results}

\section{Characteristics of Studies}

According to the inclusion and exclusion criteria, a total of 13 studies were included in our systematic literature search. A flow diagram that shows how we located relevant studies is presented in Figure 1. Table 1 summarizes the baseline characteristics of the included studies. Seven $[11,14-19]$ studies involved thyroid disease, and 7 [12, $18,20-24]$ studies involved thyroid medication. It is worth noting that data for both thyroid disease and medication were extracted from 1 article [18].

\section{Thyroid Disease and the Risk of AMD}

Seven studies with a total of 61,993 patients reported the relationship between thyroid disease and AMD. The presence of thyroid disease was associated with a $25 \%$ increase in the risk of AMD in humans (summary RR: 1.25; 95\% CI: 1.02, 1.54) (Fig. 2). Statistically significant heterogeneity was observed in the study results $\left(I^{2}=80.1 \%\right.$, $p<0.001)$. 


\begin{tabular}{l} 
Study \\
ID \\
\hline Friedman E 1989 [14] \\
Bromfield S 2012 [15]
\end{tabular}

Fig. 2. Forest plot for the association between thyroid disease and AMD. AMD, age-related macular degeneration.

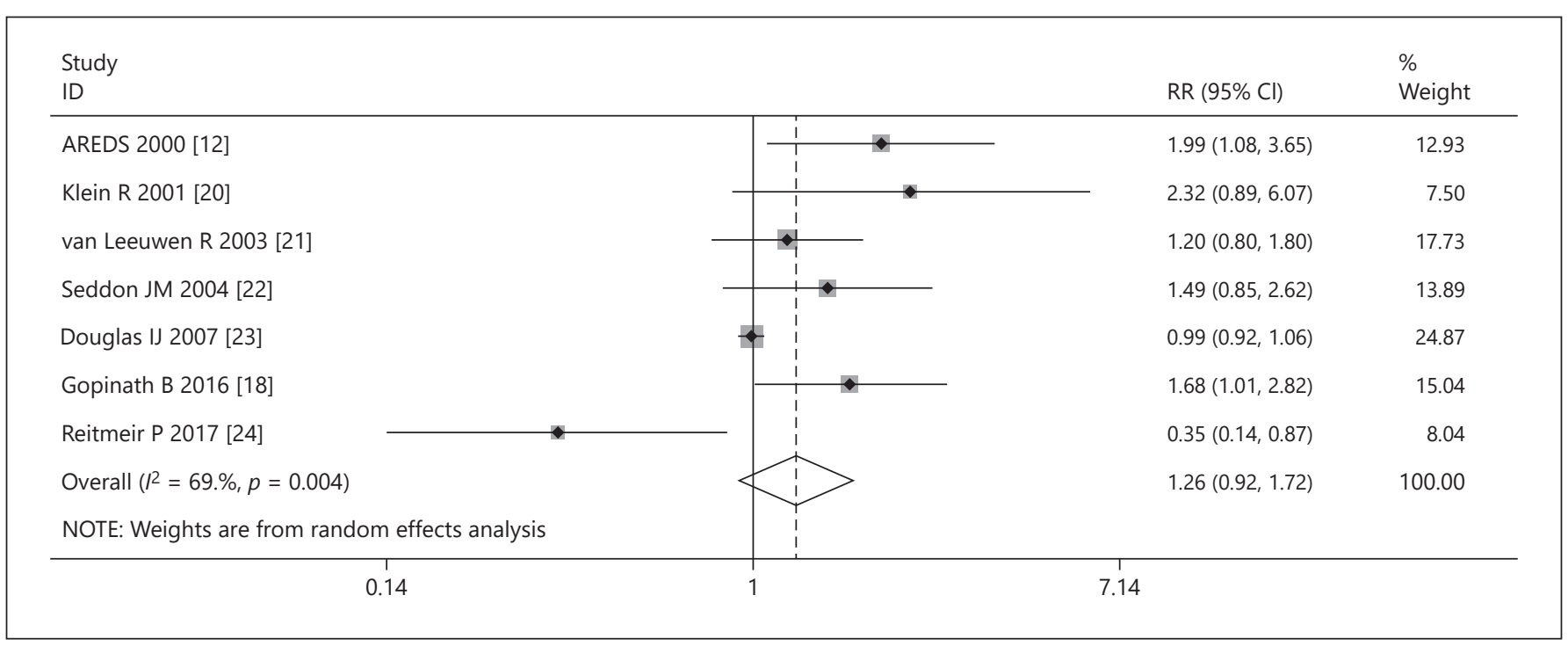

Fig. 3. Forest plot for the association between thyroid medication and AMD. AMD, age-related macular degeneration.

Thyroid Medication and the Risk of AMD

Seven studies with a total of 118,420 patients reported the relationship between thyroid medication and AMD. The random-effects model was used for meta-analysis, and the results showed a pooled RR (95\% CI) for the association between thyroid medication and AMD of 1.26 (0.92-1.72), which was heterogeneous $\left(I^{2}=69.0 \%, p=\right.$ 0.004 ), as shown by the forest plots (Fig. 3 ).

\section{Publication Bias}

Egger's test was used to evaluate publication bias. There was no indication of a publication bias for the thyroid disease $(p=0.889)$ or thyroid medication $(p=0.226)$ results, as shown by the funnel plots (Fig. 4,5 ). 


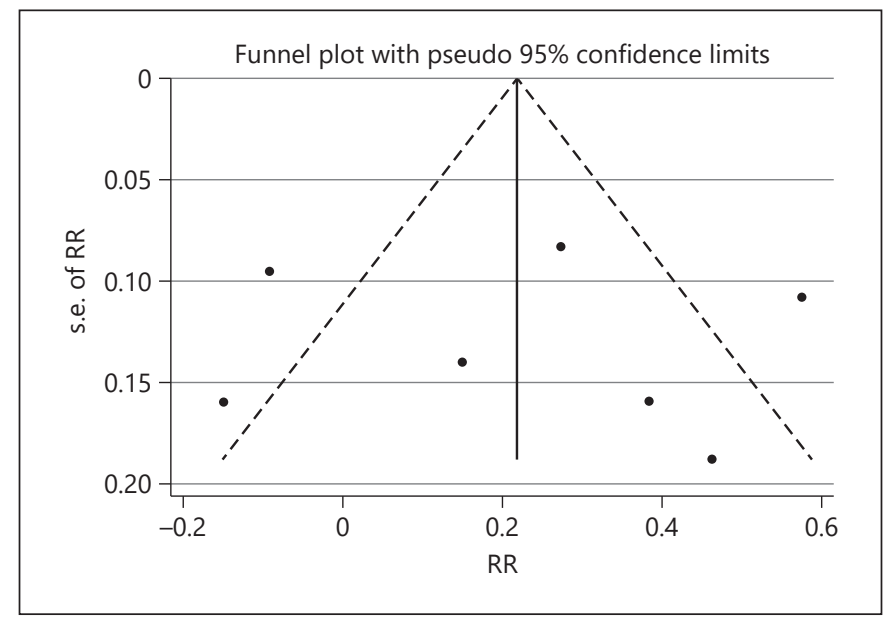

Fig. 4. Funnel plot for the association between thyroid disease and AMD. AMD, age-related macular degeneration.

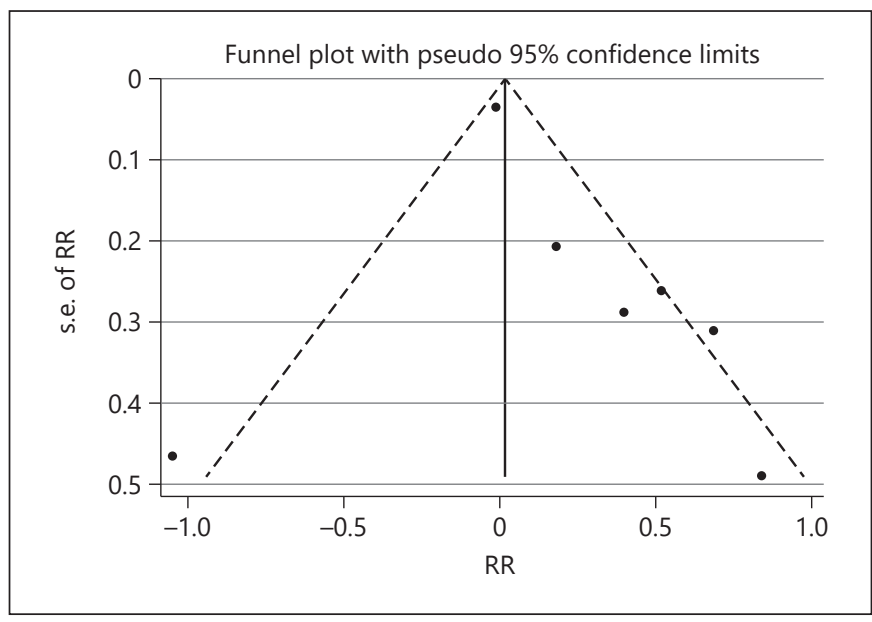

Fig. 5. Funnel plot for the association between thyroid medication and AMD. AMD, age-related macular degeneration.
Fig. 6. Sensitivity analyses for the association between thyroid disease and AMD. $\mathrm{AMD}$, age-related macular degeneration.
Meta-analysis estimates, given named study is omitted

$$
\text { I Lower Cl limit o Estimate I Upper Cl limit }
$$

Friedman E 1989 [14]

Bromfield S 2012 [15]

Park SJ 2014 [16]

Chaker L 2015 [11]

Tsai DC 2015 [17]

Gopinath B 2016 [18]

Abdelkader M 2019

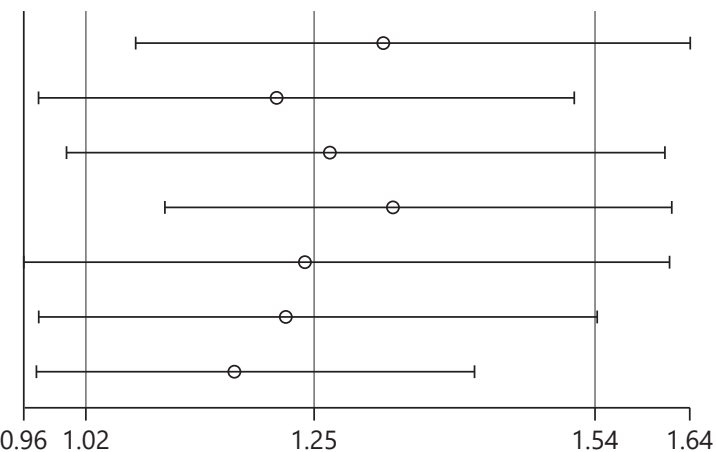

Fig. 7. Sensitivity analyses for the association between thyroid medication and AMD. AMD, age-related macular degeneration.
Meta-analysis estimates, given named study is omitted

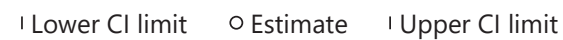

AREDS 2000 [12]

Klein R 2001 [20]

van Leeuwen R 2003 [21]

Seddon JM 2004 [22]

Douglas IJ 2007 [23]

Gopinath B 2016 [18]

Reitmeir P 2017 [24]

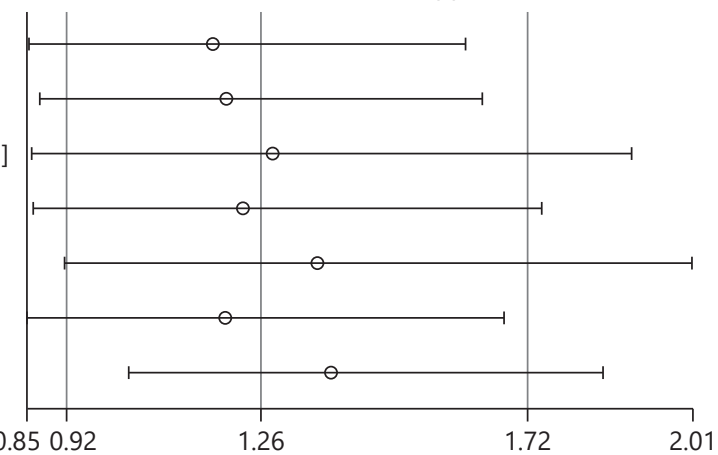




\section{Sensitivity Analysis}

In sensitivity analyses, we recalculated the combined results by excluding 1 study per iteration. Overall, the results of the sensitivity analysis were similar to those of the original analysis, and the RR estimate did not change drastically in the meta-analysis of thyroid disease, thyroid medication, and AMD (Fig. 6, 7).

\section{Discussion}

TH signaling has been reported to regulate cell proliferation, differentiation, and metabolic homeostasis and to be involved in different visual functions, such as the function of specific cone subtypes in human retinal organoids [25]. Thyroid dysfunction and subclinical thyroid dysfunction are common in the general population, and the mean prevalence of total thyroid dysfunction in Europe was found to be $3.82 \%$ [26].

However, the mechanisms that link thyroid disease and AMD are currently unclear. It can be speculated that elevated TH levels can accelerate oxidative metabolism by inducing mitochondrial enzymes [27]. The retina is particularly susceptible to oxidative stress, and oxidative damage is thought to be one of the multiple components of the complex molecular mechanism of AMD [28]. In addition, thyroid dysfunction is related to vascular function, lipids, and atherosclerosis [29], which are known predisposing factors for the development and progression of AMD [30]. Population studies have revealed that rs943080 in the VEGF-A gene is associated with AMD and is significant in thyroid-stimulating hormone genome-wide association studies [11]. A possible explanation may be that susceptibility genes have been found in inflammation and oxidative stress pathways. Our findings suggested that thyroxine medication use also appears to play a role in influencing the risk of incident AMD. A population-based study in the region of Augsburg reported a significantly higher risk for other ophthalmic diseases in males treated with $\mathrm{TH}$ [24].

The results of the present meta-analysis were based on 7 articles and indicated that the prevalence of thyroid disease was associated with AMD (pooled RR [95\% CI]: 1.25 [1.02-1.54]). In addition, there was no statistical association between thyroid medication and AMD risk. This is the first study investigating the putative association between thyroid function and AMD in the general population.

Notwithstanding these numbers, it is difficult to evaluate what the clinical consequences of this heterogeneity may be for future settings. Therefore, we estimate the prediction interval for the RR [31]. The resulting prediction interval for RR of thyroid disease and the risk of AMD, ranging from 0.253 to 2.25 , can be interpreted as the $95 \%$ range of true RR to be expected in similar studies. The prediction interval contains values above 1 which means that the presence of thyroid disease was associated with an increase in the risk of AMD. But, it also contains values below 1 which means that the presence of thyroid disease may decrease the risk of AMD. Consequently, the result in a new study may be even the exact opposite to the estimate of the meta-analysis. On the other hand, we estimate the prediction interval for the RR of thyroid medication and the risk of AMD, ranging from 0.19 to 2.33 . The prediction interval is similar to the $95 \%$ range of RR.

There are several limitations in our study. First, a thyroxine drug effect on AMD requires a long period of exposure, and this study had insufficient information in this regard. Second, some studies adjusted for potential confounders. There was no distinction between adjusted and nonadjusted when combining effect values. Last, too few studies have reported AMD type, and consequently, it was not possible to conduct subgroup analyses according to AMD type. Further studies are needed to validate our findings and to better elucidate the influence of $\mathrm{TH}$ and medication use on the development of AMD.

\section{Conclusions}

Our results indicate that there was an increased incidence of AMD in patients with thyroid disease. Thyroid disease prevention strategies may have a significant effect on the prevention of AMD and warrant further evaluation.

\section{Supplementary Information}

The PRISMA guidelines are given in online suppl. material 1 (for all online suppl. material, see www.karger. com/doi/10.1159/000515273).

\section{Statement of Ethics}

All analyses were based on previous published studies, and thus no ethical approval and informed consent are required. Nonetheless, the study adhered fully to the Declaration of Helsinki. 


\section{Conflict of Interest Statement}

The authors have no conflicts of interest to declare.

\section{Funding Sources}

The study was supported by Anhui Provincial Department of Education Project (2019jyxm1009).

\section{Author Contributions}

L.T. conceived the study. M.Z. and Q.Z. performed and checked the available information from eligible articles in this meta-analysis. Z.X. analyzed the data and wrote the main manuscript text. T.X. reviewed and revised the manuscript. All authors read and approved the final manuscript.

\section{References}

1 Wong WL, Su X, Li X, Cheung CM, Klein R, Cheng CY, et al. Global prevalence of age-related macular degeneration and disease burden projection for 2020 and 2040: a systematic review and meta-analysis. Lancet Glob Health. 2014;2(2):e106-16.

2 Velez-Montoya R, Oliver SC, Olson JL, Fine SL, Quiroz-Mercado H, Mandava N. Current knowledge and trends in age-related macular degeneration: genetics, epidemiology, and prevention. Retina. 2014;34(3):423-41.

3 Smith AF. The growing importance of pharmacoeconomics: the case of age-related macular degeneration. Br J Ophthalmol. 2010 94(9):1116-7.

4 Klein R, Klein BE, Knudtson MD, Wong TY, Cotch MF, Liu K, et al. Prevalence of age-related macular degeneration in $4 \mathrm{racial} / \mathrm{ethnic}$ groups in the multi-ethnic study of atherosclerosis. Ophthalmology. 2006;113(3):37380

5 Hyman L, Neborsky R. Risk factors for agerelated macular degeneration: an update. Curr Opin Ophthalmol. 2002;13(3):171-5.

$6 \mathrm{Ma} \mathrm{H}$, Yang F, Ding X-Q. Inhibition of thyroid hormone signaling protects retinal pigment epithelium and photoreceptors from cell death in a mouse model of age-related macular degeneration. Cell Death Dis. 2020; 11(1):24.

7 Duncan KG, Bailey KR, Baxter JD, Schwartz DM. The human fetal retinal pigment epithelium: a target tissue for thyroid hormones. Ophthalmic Res. 1999;31(6):399-406.

8 Ittermann T, Dörr M, Völzke H, Tost F, Lehmphul I, Köhrle J, et al. High serum thyrotropin levels are associated with retinal arteriolar narrowing in the general population. Thyroid. 2014;24(10):1473-8.

9 Boyes WK, Degn L, George BJ, Gilbert ME. Moderate perinatal thyroid hormone insufficiency alters visual system function in adult rats. Neurotoxicology. 2018;67:73-83.

10 Ma H, Thapa A, Morris L, Redmond TM, Baehr W, Ding XQ. Suppressing thyroid hormone signaling preserves cone photoreceptors in mouse models of retinal degeneration. Proc Natl Acad Sci USA. 2014;111(9):3602-7.
11 Chaker L, Buitendijk GH, Dehghan A, Medici M, Hofman A, Vingerling JR, et al. Thyroid function and age-related macular degeneration: a prospective population-based cohort study-the rotterdam study. BMC Med. 2015; 13:94.

12 Age-Related Eye Disease Study Research Group. Risk factors associated with age-related macular degeneration. A case-control study in the age-related eye disease study: agerelated eye disease study report number 3 . Ophthalmology. 2000;107(12):2224-32.

13 Higgins JP, Thompson SG, Deeks JJ, Altman DG. Measuring inconsistency in meta-analyses. Bmj. 2003;327(7414):557-60.

14 Friedman E, Ivry M, Ebert E, Glynn R, Gragoudas $\mathrm{E}$, Seddon J. Increased scleral rigidity and age-related macular degeneration. Ophthalmology. 1989;96(1):104-8.

15 Bromfield S, Keenan J, Jolly P, McGwin G Jr. A suggested association between hypothyroidism and age-related macular degeneration. Curr Eye Res. 2012;37(6):549-52.

16 Park SJ, Lee JH, Woo SJ, Ahn J, Shin JP, Song SJ, et al; Epidemiologic Survey Committee of the Korean Ophthalmologic Society. Age-related macular degeneration: prevalence and risk factors from Korean national health and nutrition examination survey, 2008 through 2011. Ophthalmology. 2014;121:1756-65.

17 Tsai DC, Chen SJ, Huang CC, Yuan MK, Leu HB. Age-related macular degeneration and risk of degenerative dementia among the elderly in taiwan: a population-based cohort study. Ophthalmology. 2015;122(11):2327e2.

18 Gopinath B, Liew G, Kifley A, Mitchell P. Thyroid dysfunction and ten-year incidence of age-related macular degeneration. Invest Ophthalmol Vis Sci. 2016;57(13):5273-7.

19 Abdelkader M, Abass N. The relation between age related macular degeneration and thyroid disorders. Ijovs. 2019;4(4):101-5.

20 Klein R, Klein BE, Jensen SC, Cruickshanks KJ, Lee KE, Danforth LG, et al. Medication use and the 5-year incidence of early age-related maculopathy: the beaver dam eye study. Arch Ophthalmol. 2001;119(9):1354-9.
21 van Leeuwen R, Tomany SC, Wang JJ, Klein R, Mitchell P, Hofman A, et al. Is medication use associated with the incidence of early agerelated maculopathy? Pooled findings from 3 continents. Ophthalmology. 2004;111(6): 1169-75.

22 Seddon JM, Gensler G, Milton RC, Klein ML, Rifai N. Association between c-reactive protein and age-related macular degeneration. Jama. 2004;291(6):704-10.

23 Douglas IJ, Cook C, Chakravarthy U, Hubbard R, Fletcher AE, Smeeth L. A case-control study of drug risk factors for age-related macular degeneration. Ophthalmology. 2007; 114(6):1164-9.

24 Reitmeir P, Linkohr B, Heier M, Molnos S, Strobl R, Schulz H, et al. Common eye diseases in older adults of southern germany: results from the kora-age study. Age Ageing. 2017;46(3):481-6.

25 Eldred KC, Hadyniak SE, Hussey KA, Brenerman B, Zhang PW, Chamling X, et al. Thyroid hormone signaling specifies cone subtypes in human retinal organoids. Science. 2018; 362(6411):eaau6348.

26 Garmendia Madariaga A, Santos Palacios S, Guillén-Grima F, Galofré JC. The incidence and prevalence of thyroid dysfunction in europe: a meta-analysis. J Clin Endocrinol Metab. 2014;99(3):923-31.

27 Tsai CC, Kao SC, Cheng CY, Kau HC, Hsu WM, Lee CF, et al. Oxidative stress change by systemic corticosteroid treatment among patients having active graves ophthalmopathy. Arch Ophthalmol. 2007;125(12):1652-6.

28 Beatty S, Koh H, Phil M, Henson D, Boulton $M$. The role of oxidative stress in the pathogenesis of age-related macular degeneration. Surv Ophthalmol. 2000;45(2):115-34.

29 Biondi B, Cooper DS. The clinical significance of subclinical thyroid dysfunction. Endocr Rev. 2008;29(1):76-131.

30 Klein R, Cruickshanks KJ, Myers CE, Sivakumaran TA, Iyengar SK, Meuer SM, et al. The relationship of atherosclerosis to the 10 -year cumulative incidence of age-related macular degeneration: the beaver dam studies. Ophthalmology. 2013;120(5):1012-9.

31 IntHout J, Ioannidis JP, Rovers MM, Goeman JJ. Plea for routinely presenting prediction intervals in meta-analysis. BMJ Open. 2016 6(7):e010247. 